\title{
Bio-pellets Manufacture from Palm Fruit Skin as Renewable Alternative Fuels in Updraft Type Gasification Furnaces
}

\author{
Ridwan Abdurrahman*, Radja Masyita Aulya Syafitri, Abrar Ridwan, Lega Putri Utami \\ Mechanical Engineering Department, Universitas Muhammadiyah Riau, Pekanbaru 28294, Indonesia
}

Corresponding Author Email: ridwanabdurrahman@umri.ac.id

https://doi.org/10.18280/ijdne.150617

Received: 12 August 2020

Accepted: 24 November 2020

\section{Keywords:}

Indragiri Hilir, biomass, Nipah fruit skin, gasification furnaces, bio-pellet

\begin{abstract}
Biomass is a suitable alternative to be used as fuel, but the use of biomass without prior processing can cause respiratory disease. In Indragiri Hilir Regency, the utilization of palm fruit skin waste is still minimal. Bio-pellet is a fuel derived from biomass waste that has gone through a densification process. The process of making bio-pellets is carried out by refining the raw materials, mixing the adhesives, printing the raw materials that are pressed under high pressure, and drying. The results of the research on the bio-pellet characteristic test of Nipah fruit peel waste according to its parameters obtained an average value of $1.28 \%$ water content, $0.51 \%$ ash content, $21.3 \%$ flying substance content, $76.88 \%$ bound carbon content and weight. type $1.41 \mathrm{gr} / \mathrm{cm}^{3}$. For the combustion test in the updraft type gasification furnace with the addition of $0.5 \mathrm{~kg}, 0.3 \mathrm{~kg}$ and $0.2 \mathrm{~kg}$ of fuel, the results obtained from the rate of fuel consumption are $0.041 \mathrm{~kg} / \mathrm{minute}$, $0.033 \mathrm{~kg} /$ minute and $0.033 \mathrm{~kg}$ respectively. /minute. In the results of combustion efficiency, the value according to SNI 7926: 2013 is the addition of $0.5 \mathrm{~kg}$ of fuel at the beginning of ignition and $0.2 \mathrm{~kg}$ at the end of ignition, which is 0.04 .
\end{abstract}

\section{INTRODUCTION}

The development of the population increases the use of fossil fuels which results in the depletion of these fossil resources. Several isolated villages in Indragiri Hilir district still have difficulty getting fuel in the form of LPG gas and kerosene, so they have to replace them with firewood or charcoal.

Biomass has several advantages that can be used as fuel, one of which is that it is easy to get heat. Besides, biomass is an environmentally friendly renewable energy source. However, biomass that is used directly as fuel without any processing will cause respiratory disease [1]. To improve the characteristics of the biomass, densification was carried out, one of which was in the form of bio-pellets.

Bio-pellets are the result of pressing biomass which has greater pressure compared to briquettes, namely, $60 \mathrm{~kg} / \mathrm{m}^{3}$, $1 \%$ ash content, and less than $10 \%$ moisture content. Bio pellet has advantages, namely, easy storage, smaller size compared to briquettes, bio-pellets can also produce lower emissions from wood. The characteristics of bio pellets according to the SNI 8021-2014 standard can be seen in the following Table 1.

Table 1. Pellet requirements according to SNI 8021-2014

\begin{tabular}{cccc}
\hline No. & Parameter & Unit & Requirements \\
\hline 1 & Density & $\%$ & Min. 0.8 \\
2 & Moisture content & $\%$ & Max. 12 \\
3 & Ash content & $\%$ & Max. 1.5 \\
4 & Volatile matters & $\%$ & Max. 80 \\
5 & Fixed carbon & $\%$ & Min. 14 \\
6 & Calorific value & Cal $/ \mathrm{g}$ & Min. 4000 \\
\hline
\end{tabular}

The utilization of palm plant waste in Indragiri Hilir
Regency is still very minimal. It is feared that waste that is left unchecked will pollute the environment. The Nipah plant is a type of palm plant that grows in tidal areas near the edge of the sea. In Indragiri Hilir Regency, the area of Nipah trees is recorded, namely, 17,435 hectares.

Biomass gasification furnaces are a suitable alternative to be developed to reduce the scarcity of fossil fuels such as LPG and kerosene. Gasification is the process of converting solid fuel into combustible gas. The fuel used in the gasification process uses materials containing hydrocarbons such as coal, petroleum coke, and biomass [2]. The furnace can re-burn the combustion products through the holes around the inner tube causing gasification [3].

Bamboo fuel can be used for the Rocket Stove Combustion Process for Heating Stirling Engine [4]. The CFD model is capable of describing the fluid dynamics and chemical processes taking place in the overall combustion process, capturing known phenomena like air velocity, temperature distribution, and chemical species concentrations [5]. The experience of gasifier users concerning the effort and energy needed for wood chip preparation in a typical gasifier has led us to the development of a gasifier suitable to work with longstick woody biomass as the feed material [6]. Lignocellulosic biomass resource in China is scattered over a huge number of rural households, which results in a high cost of feedstock collection, transportation, and storage. This fact suggests that the decentralized utilization at a small or middle scale is more feasible than a large scale [7].

Steam explosion pretreatment improves the physical properties and energetic properties of biomass providing a positive approach in thermal applications [8]. the study investigated the performance of a top-lit updraft (TLUD) cookstove using three different fuel types e wood chips, 
coconut shell, and rice husk briquettes. It was observed that the type of fuel used significantly influenced $(\mathrm{p}<0.05)$ the performance of the cookstove [9]. Syngas consists mainly of $\mathrm{CO}$ and $\mathrm{H}_{2}$, are obtained from the gasification process through feedstock such as biomass, coal, refinery residual, organic waste, and municipal waste [10]. Updraft gasifier has been reported suitable essentially for thermal applications because the tar and particulates level is considerably high and observed to vary from 50 to $100 \mathrm{~g} / \mathrm{Nm}^{3}$ and above [11]. Various critical issues (technical and non-technical) related to gasification subprocesses are discussed, such as biomass supply chain management, biomass pretreatment, gasification technology, syngas conditioning, power generation through gasification, environmental issues, and other generic barriers [12].

The gasification process is carried out by using above mentioned biomass materials, in which Coconut shells gives low gas production rate $\left(1.4724 \mathrm{~m}^{3} / \mathrm{hr}\right)$ and low gasification efficiency $(46.96 \%) \&$ Sugar cane bagasse material gives high gas production rate $\left(1.5535 \mathrm{~m}^{3} / \mathrm{hr}\right)$ and high gasification efficiency $(52.86 \%)$ [13]. mathematical model by using the COMMENT code to predict the effect of various operating parameters such as equivalence ratio (ER) and feed gas temperature on the performance of an updraft gasifier HTAG (high-temperature air gasification) [14]. Updraft gasifiers provide higher efficiency but suffer the problem of poor response time [15]. The best powder size and pressing temperature that can be used to print bio pellet products from solid waste of eucalyptus and Pine Resin are powder with a size of 40 mesh at $230^{\circ} \mathrm{C}$ (based on SNI 8021-2014) [16]. The tests performed at a higher temperature and equivalence ratios resulted in a higher conversion of biomass into a poorer gas production [17].

A device like the Chromasun Micro-Concentrator (MCT), is a feasible solution in this range of small-scale installments, thanks to its high efficiency and the high peak temperature of the mean fluid, compared to traditional Solar Thermal units [18]. A unique approach (i.e., designed, fabricated, and evaluated) of top and bottom feeding design has enabled multifuel usage [19]. From the tests emerges the good capability of the stove to handle vine-prunings derived pellets with the suggestion to increase the cleaning rate of the fireplace to allow the 365 discharge of the higher ash production [20]. The main areas for investigation include (1) developing novel designs for smaller scale, distributed waste gasification, (2) reducing the cost of syngas cleanup, (3) improving methods to utilize syngas (e.g., in fuel cells or chemical synthesis), and (4) research into using the residual ash and slag in higher-value products such as building materials [21]. An in-depth discussion throughout this review guided the high-efficiency gasification of biomass. Some high-performance gasification catalyst and their catalytic pathways were concluded, and the influence of various parameters (gasifiers, S/C ratio, reaction temperature, etc.) was discussed as a whole [22]. Escalating environmental issues due to greenhouse emissions have necessitated the need to adopt energy-efficient technologies [23]. A higher concentration of $\mathrm{CO}, \mathrm{H}_{2}$, and $\mathrm{CH}_{4}$ was observed at higher all thermal temperatures when straw gasification was performed and it is comparable to wood pellet [24].

Some optimal options of technology towards an assigned task will depend upon various circumstances including raw material availability, outline economy, and environmental affairs including lifecycle evaluation factors towards the aspired product [25]. The production of sustainable aviation fuels from biomass and residuals wastes is a new endeavor and pioneer plants can expect to face integration challenges and take time to achieve their design capacities [26]. The gasification process parameters have ranges that, in general, are similar for the gasification of different types of biomass. This indicates that obtaining higher amounts of syngas or, higher quality syngas depends on the operating or design restrictions of the gasification system, rather than on the type of biomass available [27].

Conclusively, diversity in features and limitations on the measurements of biomass restricts it for utilization in largescale applications, but this issue can be compensated by mixing municipal solid waste with different biomass [28]. Energy scarcity, its supply uncertainties, and the related environmental issues are concerns that can be solved sustainably by using biomass-derived chars. To evaluate the role of chars in future development in the energy field, an overview of the main research studies in the field was presented to identify the actual trends and highlight future challenges [29].

\section{METHODOLOGY}

The research was conducted at the Physics Laboratory of Muhammadiyah University of Riau, in July 2020.

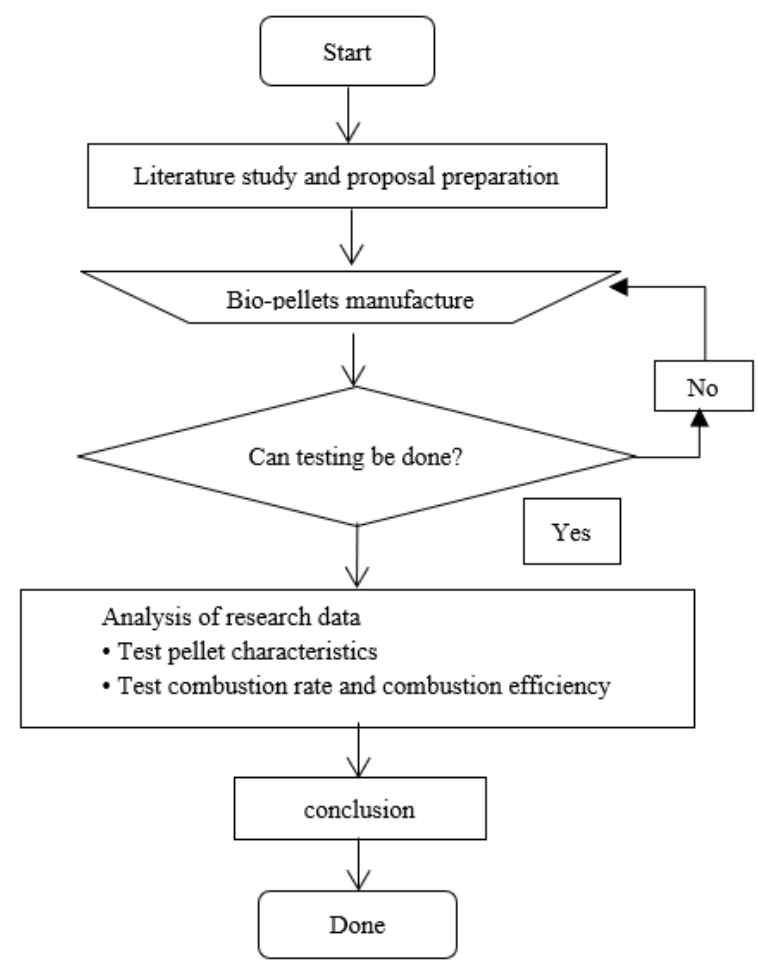

\subsection{Tools and materials}

In this research, some several tools \& materials have been used such as:

- Bio-pellets printing press, it's shown in Figure 1,

- Digital scales with accuracy is $0.01 \mathrm{~g}$,

- Raw material refining machine,

- Raw material powder filter with sizes 40mesh and 60mesh,

- Oven with a maximum temperature of $250^{\circ} \mathrm{C}$. Used for drying bio pellets,

- Porcelain cup weighing $107.83 \mathrm{~g}$. Used to put pellet samples in the characteristic testing process, it's shown in Figure 2. 


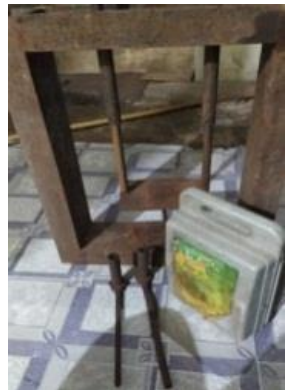

Figure 1. Bio-pellets manual printer

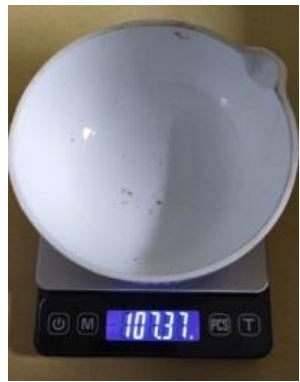

Figure 2. Porcelain cup

- The updraft type gasification furnace is used for combustion testing, it's shown in Figure 3.

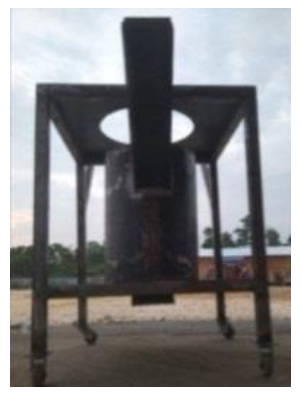

Figure 3. Updraft type biomass gasification furnace

- Thermocouple BTM-4208SD with 12 channels, it's shown in Figure 4.

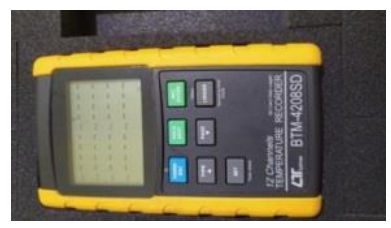

Figure 4. Thermocouple

Stopwatch,

Water container,

Measuring cup,

- The raw material used is a waste of palm fruit skin and the adhesive used is tapioca flour, it's shown in Figure 5.

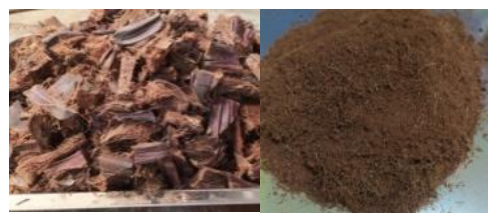

Figure 5. The raw material

\subsection{Stages of research}

\subsubsection{Bio-pellets manufacture}

Prepare the raw materials, namely the waste of Nipah fruit skin that has been chopped, then dried for 1-2 days, then mashed and filtered where the powder passes through the 40 mesh filter and is stuck on 60mesh sieving so that the particle size is more even.

Prepare the adhesive, namely tapioca flour, weigh $\pm 50 \mathrm{gr}$ of raw material powder, and weigh $5 \%$ of tapioca flour. The two ingredients are placed in different containers. Tapioca flour is cooked on low heat for \pm 5 minutes with a ratio of water and flour is 3: 1, then mix the two ingredients until evenly distributed, let stand a few minutes before printing so that the pellet dough is not sticky when printing.

The pellet dough is then put in a pipe-shaped mold and pressed using a pellet mold that has been prepared. After pressing the molds are removed from the mold and arranged in the container provided, cut the pellets to a uniform size, do the same process until all the pellet dough is finished printing, and store the pellets in a closed container.

\subsubsection{Testing of bio-pellets characteristics}

- Moisture content

Put a mass sample of $2.07 \mathrm{~g}, 2.01 \mathrm{~g}$, and $2.00 \mathrm{~g}$ on a porcelain dish. Then dried in an oven at $105^{\circ} \mathrm{C}$ for 3 hours, then weighed. The formula used to calculate the moisture content value is [30]:

$$
\text { Moisture (\%) }=\frac{B B-B K T}{B K T} \times 100 \%
$$

\section{Keterangan:}

$\mathrm{BB}=$ fule before drying $(\mathrm{g})$.

$\mathrm{BKT}=$ fule after drying $(\mathrm{g})$.

\section{- Ash content}

Put the sample into a known weight porcelain dish. Then oven at $250^{\circ} \mathrm{C}$ for 6 hours, weighed. The formula for calculating the value of ash content is as follows:

$$
\text { Ash }(\%)=\frac{\text { ash weight }(g r)}{\text { kiln dry sample weight }(g r)} \times 100 \%
$$

\section{- Volatile matters}

Put the sample on a known weight porcelain dish. Then oven at $250^{\circ} \mathrm{C}$ for 1 hour, weighed. The formula used is:

$$
\text { Volatile matters }(\%)=\frac{B-C}{W} \times 100 \%
$$

where,

B: the sample weight from the moisture test after drying (gr),

$\mathrm{C}$ : The sample weight is dried in the kiln (gr),

$\mathrm{W}$ : the sample weight before moisture testing (gr).

\section{- $\quad$ Fixed carbon}

$$
\mathrm{KKT} \%=100 \%-\left(\begin{array}{c}
\text { moisture }+ \text { ash content }+ \text { volatile } \\
\text { matters })
\end{array}\right.
$$

\section{- Density}

The determination of sample density is expressed in the results of the ratio between the mass and volume of each sample. The height value of each sample is measured using a ruler [30]. 


$$
\mathrm{BJ}=\frac{\text { Mass }}{\text { Volume }}=\frac{g r}{l}
$$

- Calorific value

Expressed based on proximate data, namely, the value of water content (MC), ash content (AC), flight substance content (VM), and bound carbon content (FC), using the following equation [30]:

$$
\begin{gathered}
\mathrm{HHV}=0.6042 \mathrm{FC}+0.4083 \mathrm{VM}+0.2442 \mathrm{AC}+0.4107 \\
\mathrm{MC}-25.204
\end{gathered}
$$

where,

$$
\begin{aligned}
& \mathrm{HHV}=\text { Calor } \\
& \mathrm{FC}=\text { Fixed carbon } \\
& \mathrm{VM}=\text { volatile matters } \\
& \mathrm{AC}=\text { ash content } \\
& \mathrm{MC}=\text { moisture content }
\end{aligned}
$$

2.2.3 Combustion testing in gasification furnaces

- Weigh the fuel with a weight variation of $0.5 \mathrm{~kg}, 0.3 \mathrm{~kg}$, and $0.2 \mathrm{~kg}$,

- Prepare a biomass gasification furnace, thermocouple, tools, and other materials for combustion tests,

- Prepare the stopwatch for time measurement,

- Set the placement of the furnace according to the scope with a spacing of 1 meter,

- $\quad$ Put fuel into the furnace

- Turn on the fire, turn on the stopwatch,

- Put a pot of $1 \mathrm{~kg}$ of water,

- Observe changes in water and fuel temperature every 3 minutes.

- Observe the concentration of $\mathrm{CO}(\mathrm{ppm})$ and $\mathrm{CO}_{2}(\mathrm{ppm})$ every 3 minutes.

- Observe the length of time the fuel burns for each additional fuel.

- Calculate the rate of fuel consumption using a formula:

$$
\mathrm{S}_{\mathrm{c}}=\frac{\Delta m_{k}}{\Delta t}
$$

where,

$\Delta m_{k}=$ mass of fuel used (gr).

$\Delta t=$ duration of testing (s)

- Calculate combustion efficiency using the formula:

$$
\eta_{c}=1-\frac{N_{C O}}{N_{C O_{2}}}
$$

where,

$\mathrm{N}=$ The mass fraction of each gas (ppm).

\section{RESULTS AND DISCUSSION}

Bio-pellets from palm fruit peel waste are printed using a manual printer with the help of pressing using a hydraulic jack, it's shown in Figure 6.

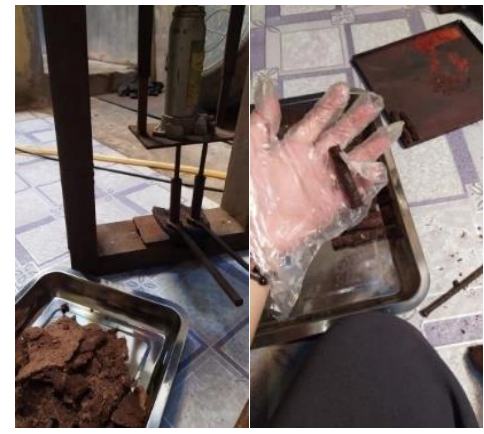

Figure 6. Bio-pellets manufacture

\subsection{Bio-pellets characteristic test results}

Each pellet characteristic test was carried out using varied sample weights, namely $2.00 \mathrm{gr}, 2.01 \mathrm{gr}$, and $2.07 \mathrm{gr}$, it's shown in Figure 7 . The varied sample weights function to determine the effect of the amount of water content in the pellet sample on the density of the pellet sample. The results of the bio-pellet characteristic test can be seen in Table 2 .
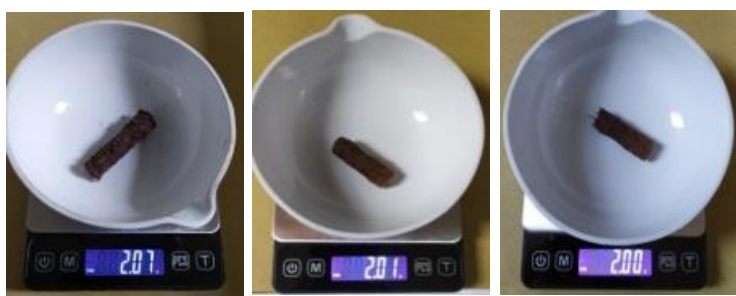

Figure 7. Sample mass characteristic testing of bio-pellets

\section{- Moisture content}

Based on the graph above, it is known that the highest water content value is in the sample mass weighing $2.01 \mathrm{gr}$, namely, $1.31 \%$. This is because in the densification process in the form of bio-pellets the emphasis used is lower than the other samples so that the resulting density or density value is reduced. Bio-pellets density or density greatly affects the amount of water content.

While the lowest water content value was found in the sample mass weighing $2.07 \mathrm{gr}$, namely, $1.23 \%$. Based on the results of the analysis that the sample mass of 2.07 has a high density or density value, this is because the densification process in the form of bio-pellets is used higher than the sample mass of 2.01 so that the resulting density or density value is higher. increased. The solid pellets can reduce the moisture content of the pellets, it's shown in Figure 8. However, the test results of the water content value in all samples were following the SNI 8021-2014 standard, where the standard set was $<12 \%$.

Table 2. The results of the bio-pellet characteristic test of palm fruit peel waste

\begin{tabular}{cccccc}
\hline Parameter & $\mathbf{2 . 0 0}$ & Sample Mass (gr) & $\mathbf{2 0 7}$ & Mean & SNI 8021-2014 \\
\hline Moisture content (\%) & 1.30 & 1.31 & 1.23 & 1.28 & Maks. 12 \\
Ashcontent (\%) & 0.48 & 0.51 & 0.52 & 0.51 & Maks. 1.5 \\
Volatile matters (\%) & 22 & 21 & 21 & 21.3 & Maks. 80 \\
Fixed Carbon (\%) & 76.21 & 77.18 & 77.25 & 76.88 & Min. 14 \\
Calorific value $(\mathrm{MJ} / \mathrm{kg})$ & 30,4758 & 30,6650 & 30,6769 & 30,6059 & Min. $4000(\mathrm{kal} / \mathrm{gr})$ \\
Specific gravity $\left(\mathrm{gr} / \mathrm{cm}^{3}\right)$ & 1.50 & 1.28 & 1.46 & 1.41 & Min. 0.8 \\
\hline
\end{tabular}




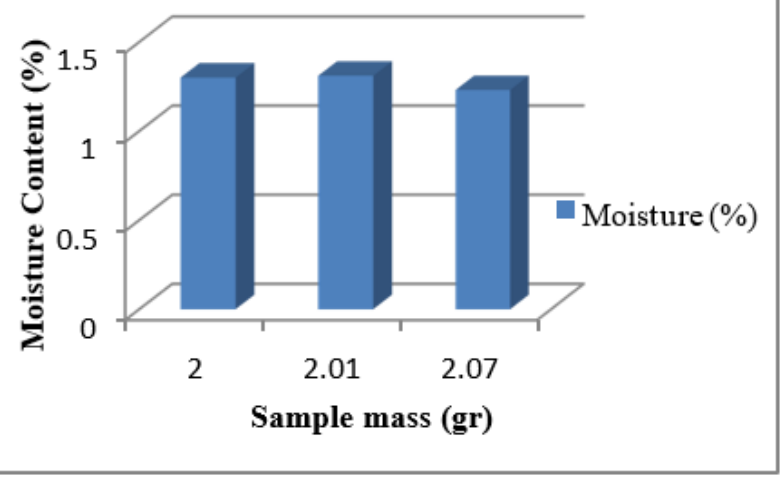

Figure 8. Moisture content vs bio-pellets sample mass

- Ash content

Based on the graph above, it can be seen that the highest ash content value is $0.52 \%$, namely the sample mass of $2.07 \mathrm{gr}$. This is because the sample mass of $2.07 \mathrm{~g}$, the amount of Nipah fruit shell powder is more than the amount of coconut husk. According to previous studies, the amount of ash content in the Nipah fruit shells was about $1 \%$. High ash content risks the formation of mineral deposits during the combustion process, resulting in a dirty furnace surface.

While the lowest ash content value is $0.48 \%$ in the sample mass of $2.00 \mathrm{gr}$. In this test, the high-density value of biopellets did not affect the value of the bio-pellet ash content but only affected the value of the moisture content. For the value of ash content in the sample mass of $2.01 \mathrm{gr}$, the test results obtained were $1.51 \%$. These results do not get a large enough difference when compared with a sample mass of $2.07 \mathrm{gr}$, so this does not require further testing, it's shown in Figure 9. However, the results of the test for the ash content of biopellets showed that the entire sample mass had met the SNI 8021-2014 standard, where the standard set was $<1.5 \%$.

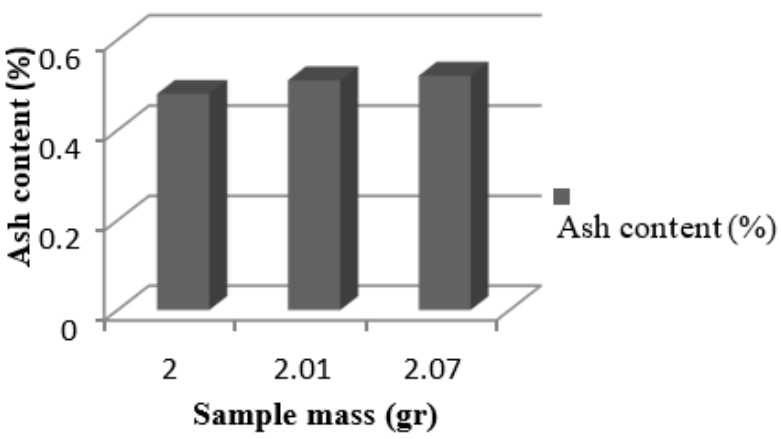

Figure 9. Ash content vs bio-pellets sample mass

\section{- Volatile matters}

From the graph above, it can be seen that the highest value of flying substances is $22 \%$ in the sample mass of $2.00 \mathrm{gr}$. This is because, in the process of testing the levels of flying substances, the temperature used is quite low, namely $250^{\circ} \mathrm{C}$ and the drying time is quite long, which is 1 hour. Meanwhile, according to the SNI 8021-2014 standard, testing the levels of flying substances is carried out using a temperature of $950^{\circ} \mathrm{C}$ for 10 minutes.

In the sample mass of $2.01 \mathrm{gr}$ and $2.07 \mathrm{gr}$, the resulting levels of flying substances were the same, namely, $21 \%$. These results do not have a significant difference when compared with the sample mass of $2.00 \mathrm{gr}$, it's shown in Figure 10 . However, in this study, the results of testing the bio-pellet flying substance content of palm fruit peel waste seemed to meet the SNI 8021-2014 standard, where the standard set was $\leq 80 \%$.

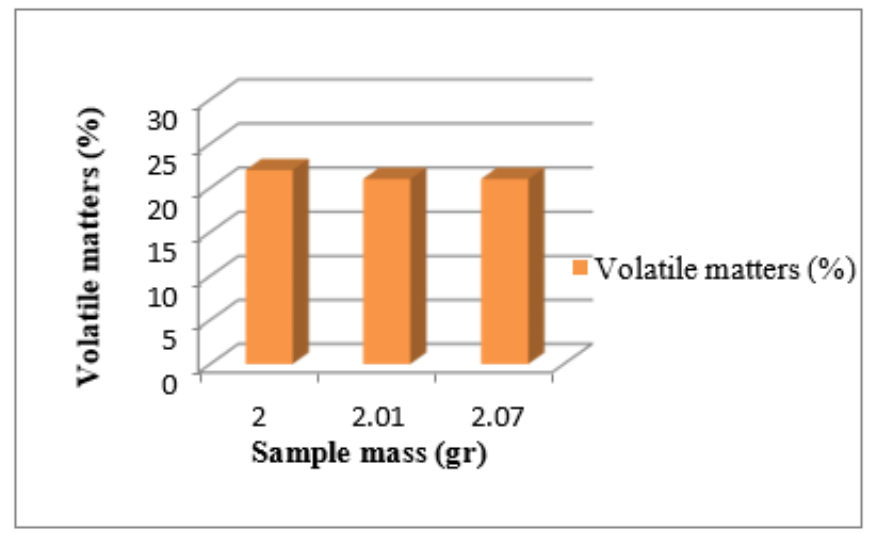

Figure 10. Volatile matters vs bio-pellets sample mass

\section{- $\quad$ Fixed carbon}

Based on the graph above, it is known that the highest amount of bound carbon content is $77.25 \%$ at a sample mass of $2.07 \mathrm{gr}$. This is due to the high value of the resulting ash content in the sample mass.

While the value of the lowest bound carbon content was $76.21 \%$ in the sample mass of $2.00 \mathrm{gr}$, the low content of bound carbon was obtained due to the low ash content produced in the sample mass, it's shown in Figure 11. In this study, the test results of the carbon content value have been under the SNI 8021-2014 standard, where the bound carbon content standard is set, namely, at least $14 \%$.

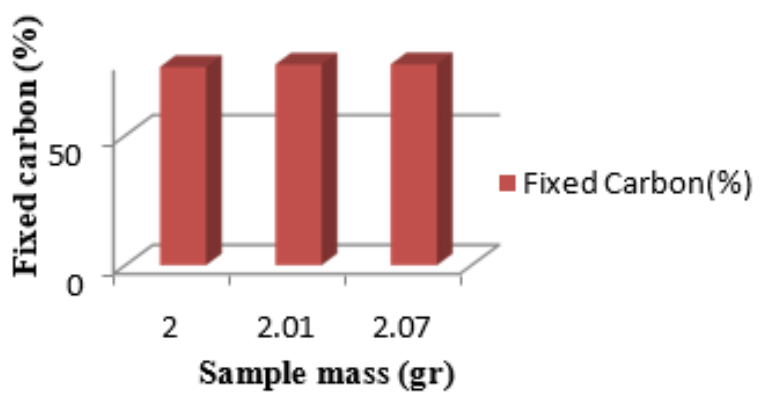

Figure 11. Fixed carbon vs bio-pellets sample mass

\section{- $\quad$ Specific gravity}

Based on the graph above, it is known that the highest density is $1.50 \mathrm{gr} / \mathrm{cm}^{3}$ with a length of $1.7 \mathrm{~cm}$. The highdensity value at the sample mass of $2.00 \mathrm{gr}$ is proven to affect the low value of water content, this is due to the large emphasis on the densification process in the form of bio-pellets so that the resulting bio-pellets are denser.

For the lowest specific gravity value, namely, $1.28 \mathrm{gr} / \mathrm{cm}^{3}$ with a length of $2 \mathrm{~cm}$. The low density of the pellets affects the high value of the moisture content, it's shown in Figure 12. This is due to the fragility of the emphasis on the densification process in the form of bio-pellets so that the bio-pellets produced have large spaces or pores and can produce high water content values. 


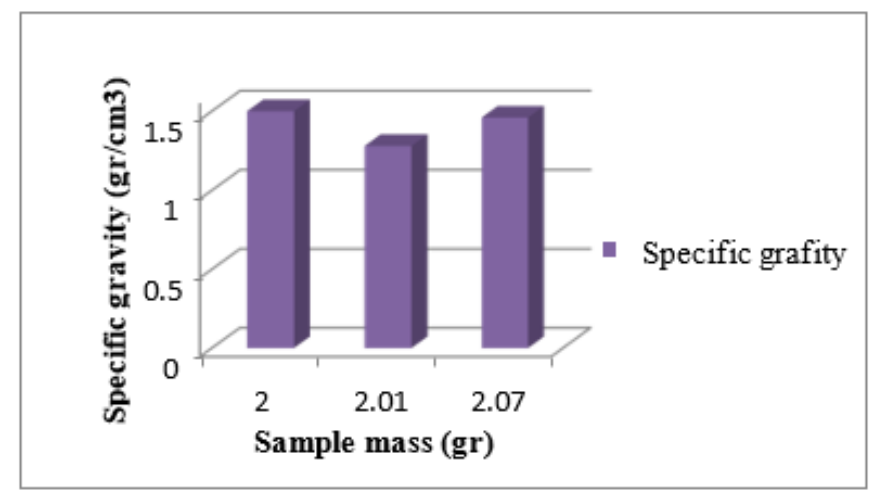

Figure 12. Specific gravity vs bio-pellets sample mass

\section{- Calorific Value}

In the graph above, it can be seen that the lowest calorific value is found in the sample mass of $2.00 \mathrm{gr}$. This is due to the low value of the bound carbon content, while the highest calorific value is found in the sample mass of $2.07 \mathrm{gr}$, it's shown in Figure 13. This is because the value of the bound carbon content is higher than the mass of the other samples.

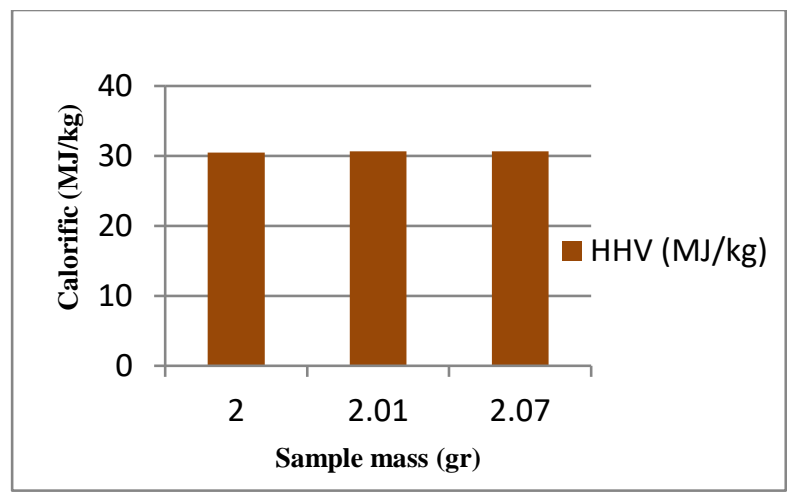

Figure 13. Calorific value vs bio-pellets sample mass

\subsection{Result of combustion test in the gasification furnace}

The combustion testing process was carried out by varying the weight of added fuel, namely $0.5 \mathrm{~kg}, 0.3 \mathrm{~kg}$, and $0.2 \mathrm{~kg}$ using bio-pellets at a sample mass of 2.00 gr. Observations were started when the fuel was ignited every 3 minutes, and the observations observed were changes in fuel temperature after ignition, changes in water temperature, $\mathrm{CO}$ concentration, and $\mathrm{CO}_{2}$ concentration, it's shown in Figure 14.

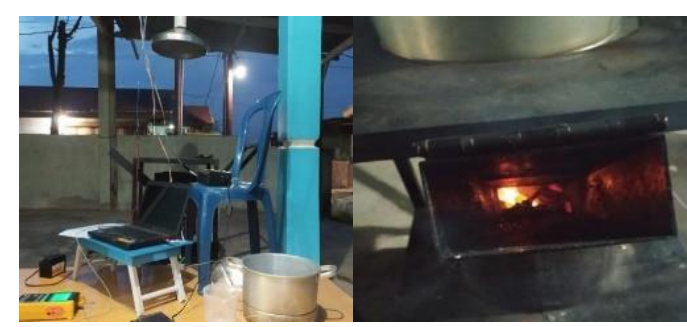

Figure 14. Combustion testing

Fuel consumption rate

From the graph above, it is found that the highest specific fuel consumption rate is the addition of $0.5 \mathrm{~kg}$ of fuel. this is due to the large amount of fuel used in the combustion process. Whereas with the addition of $0.3 \mathrm{~kg}$ and $0.2 \mathrm{~kg}$ of fuel, the specific consumption rate of the fuel produced is lower than the addition of $0.5 \mathrm{~kg}$ of fuel, it is known that the higher the temperature in the combustion chamber and the less the amount of fuel added to the fast the rate of fuel consumption, it's shown in Figure 15. In testing the fuel consumption rate, the results obtained are not under the SNI 7926-2013 standard where the standard set is a maximum of $1 \mathrm{~kg} / \mathrm{hour}$. The consumption rate is not up to standard because the fuel density value is still relatively small.

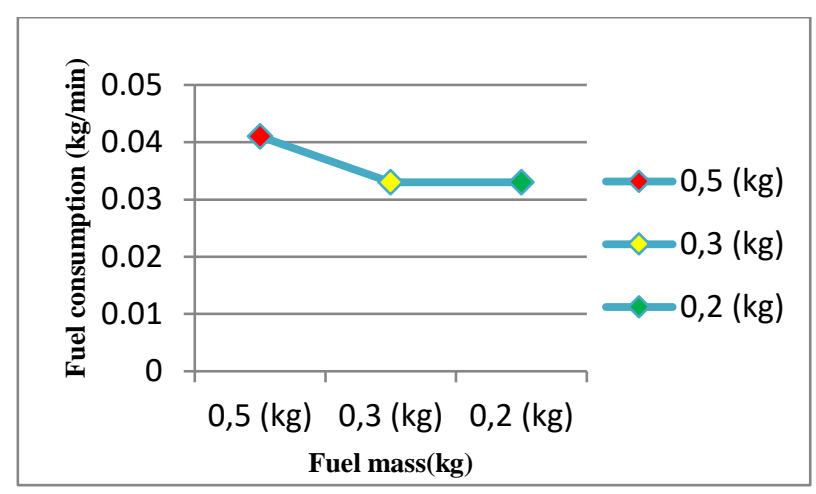

Figure 15. Fuel consumption vs fuel mass

\section{- Combustion efficiency}

In the graph of combustion efficiency with variations in the addition of fuel, it can be seen that the highest combustion efficiency value is found during the combustion test with the addition of $0.5 \mathrm{~kg}$ of fuel in the $3 \mathrm{rd}$ minute and the addition of $0.2 \mathrm{~kg}$ of fuel in the 6 th minute because of the amount $\mathrm{CO}_{2}$ gas larger than $\mathrm{CO}$ gas produced when the testing process, that mean the combustion process is more complete, it's shown in Figure 16.

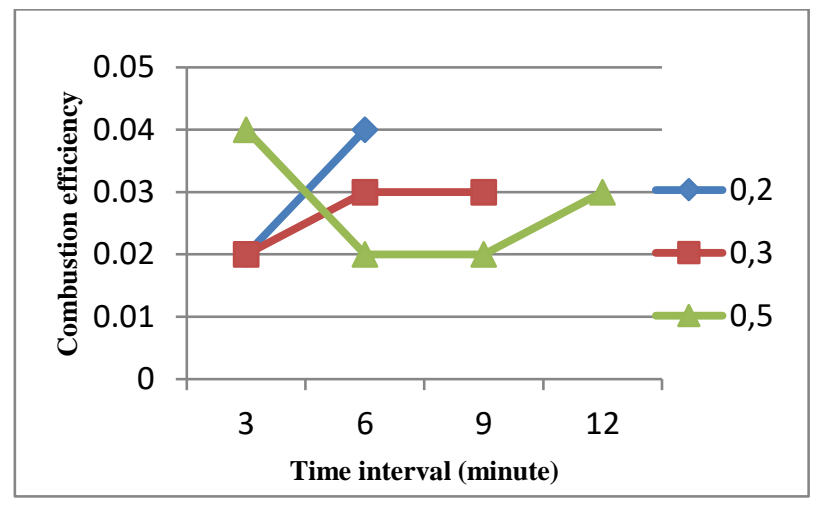

Figure 16. Combustion efficiency vs fuel mass

\section{CONCLUSION}

Different affiliations shall be listed in separate lines. Do not insert any punctuation at the end of each affiliation. If all the authors are affiliated with the same organization, type that affiliation just once.

- The results of the bio pellet characteristics test from the waste of Nipah fruit skin, the average values obtained are $1.28 \%$ water content, $0.51 \%$ ash content, $21.3 \%$ flying matter content, 76 bound carbon content, $88 \%$, heating value $30.6059 \mathrm{MJ} / \mathrm{kg}$ and specific gravity $1.41 \mathrm{gr} / \mathrm{cm}^{3}$. In the research on the characteristics of bio-pellets from palm fruit peel waste, almost all of the parameters have 
met the SNI 8021-2014 standard except for the calorific value of bio-pellets, because the test results on these parameters have not known the value.

Combustion test results. In terms of the specific fuel consumption rate, the results obtained are not under the SNI 7926-2013 standard, the standard set is a maximum of $1 \mathrm{~kg} /$ hour, while the average yield obtained $\mathrm{g} /$ hour is $1.64 \mathrm{~kg} /$ hour $-2.01 \mathrm{~kg} /$ hour. For the test results of the combustion efficiency value of bio-pellets from palm fruit peel waste in an updraft type biomass gasification furnace with variations in the addition of fuel weight under SNI $7926-2013$ standards, is the addition of $0.5 \mathrm{~kg}$ of fuel at the beginning of ignition and $0.2 \mathrm{~kg}$ at the end. ignition i.e., 0.04. and the standard set is a minimum of 0.04 to a maximum of 0.96 .

\section{ACKNOWLEDGMENT}

Thank a lot to the research and technology institute of the Higher Education in the Village Development Grant Program (PHBD), which is a program of the Directorate General of Higher Education, Mendikbud.

\section{REFERENCES}

[1] Yamada, K.M., Kanada, Q., Wang, K., Sakamoto, I., Uchiyama, T.M., Zhou, Y. (2005). The utility of coalbiomass briquette for remediation of indoor air pollution caused by coal burning in rural area, in China. Proceedings of the 10th International Conference on Indoor Air Quality and Climate, pp. 3671-3675.

[2] Subroto, S. (2017). Kinerja tungku gasifikasi downdraft continue bahan bakar sekam padi. Media Mesin: Majalah Teknik Mesin, 18(1): 24-33. https://doi.org/10.23917/mesin.v18i1.3946

[3] Ridwan, A., Istana, B. (2014). Rancang bangun tungku gasifikasi biomasa hemat energi dan ramah lingkungan penghasil listrik. Photon: Jurnal Sain Dan Kesehatan, 4(2): 47-57. https://doi.org/10.37859/jp.v4i2.181

[4] Abdurrahman, R., Pasek, A.D., Prawisudha, P. (2018). Numerical and experimental study on rocket stove combustion process for heating stirling engine. AIP Conference Proceedings, p. 030012. https://doi.org/10.1063/1.5046633

[5] Kalla, S., Marcoux, H., Champlain, A. (2015). CFD approach for modeling high and low combustion in a natural draft residential wood log stove. International Journal of Heat and Technology, 33(1): 33-38. https://doi.org/10.18280/ijht.330105

[6] Saravanakumar, A., Haridasan, T.M., Reed, T.B., Bai, R.K. (2005). Operation and modelling of an updraft longstick wood gasifier. Energy for Sustainable Development, 9(4): 25-39. https://doi.org/10.1016/S09730826(08)60497-4

[7] Zhang, K., Chang, J., Guan, Y., Chen, H., Yang, Y., Jiang, J. (2013). Lignocellulosic biomass gasification technology in China. Renewable Energy, 49: 175-184. https://doi.org/10.1016/j.renene.2012.01.037

[8] Gunarathne, D.S., Mueller, A., Fleck, S., Kolb, T., Chmielewski, J.K., Yang, W., Blasiak, W. (2014). Gasification characteristics of steam exploded biomass in an updraft pilot scale gasifier. Energy, 71: 496-506. https://doi.org/10.1016/j.energy.2014.04.100

[9] Obi, O.F., Ezeoha, S.L., Okorie, I.C. (2016). Energetic performance of a top-lit updraft (TLUD) cookstove. Renewable Energy, 99: 730-737. https://doi.org/10.1016/j.renene.2016.07.060

[10] Samiran, N.A., Jaafar, M.N.M., Ng, J.H., Lam, S.S., Chong, C.T. (2016). Progress in biomass gasification technique - with focus on Malaysian palm biomass for syngas production. Renewable and Sustainable Energy Reviews, 62: 1047-1062. https://doi.org/10.1016/j.rser.2016.04.049

[11] Sansaniwal, S.K., Pal, K., Rosen, M.A., Tyagi, S.K. (2017). Recent advances in the development of biomass gasification technology: A comprehensive review. Renewable and Sustainable Energy Reviews, 72: 363384. https://doi.org/10.1016/j.rser.2017.01.038

[12] Sansaniwal, S.K., Rosen, M.A., Tyagi, S.K. (2017). Global challenges in the sustainable development of biomass gasification: An overview. Renewable and Sustainable Energy Reviews, 80: 23-43. https://doi.org/10.1016/j.rser.2017.05.215

[13] Venkatesh, G., Ramakrishna Reddy, P., Kotari, S. (2017) Generation of producer gas using coconut shells and sugar cane bagasse in updraft gasifier. Materials Today: Proceedings, 4(8): 9203-9209. https://doi.org/10.1016/j.matpr.2017.07.278

[14] Ismail, T.M., El-Salam, M.A. (2017). Parametric studies on biomass gasification process on updraft gasifier high temperature air gasification. Applied Thermal Engineering, 112: 1460-1473. https://doi.org/10.1016/j.applthermaleng.2016.10.026

[15] Kumar, G.S., Gupta, A., Viswanadham, M. (2018). Design of lab-scale downdraft gasifier for biomass gasification. IOP Conference Series: Materials Science and Engineering, 455: 012051. https://doi.org/10.1088/1757-899X/455/1/012051

[16] Mustamu, S., Hermawan, D., Pari, G. (2018). Karakteristik biopelet dari limbah padat kayu putih dan gondorukem. Jurnal Penelitian Hasil Hutan, 36(3): 191204. https://doi.org/10.20886/jphh.2018.36.3.191-204

[17] Ismail, T.M., Abd El-Salam, M., Monteiro, E., Rouboa, A. (2018). Fluid dynamics model on fluidized bed gasifier using agro-industrial biomass as fuel. Waste Management, 73: 476-486. https://doi.org/10.1016/j.wasman.2017.06.018

[18] Puglia, M., Rizzo, A., Morselli, N., Tartarini, P. (2019). Efficiency and economical assessment of a solar powered dryer combined with a biomass gasification system. International Journal of Heat and Technology, 37(3): 705-709. https://doi.org/10.18280/ijht.370306

[19] Gupta, A., Mulukutla, A.N.V., Gautam, S., TaneKhan, W., Waghmare, S.S., Labhasetwar, N.K. (2020). Development of a practical evaluation approach of a typical biomass cookstove. Environmental Technology \& Innovation, 17 : 100613. https://doi.org/10.1016/j.eti.2020.100613

[20] Pedrazzi, S., Morselli, N., Puglia, M., Tartarini, P. (2020). Energy and emissions analysis of hemp hurd and vine pruning derived pellets used as fuel in a commercial stove for residential heating. Tecnica Italiana-Italian Journal of Engineering Science, 64(2-4): 361-638. https://doi.org/10.18280/ti-ijes.642-435

[21] Perkins, G. (2020). Production of electricity and chemicals using gasification of municipal solid wastes. 
Waste Biorefinery, $\quad$ Elsevier, 39. https://doi.org/10.1016/B978-0-12-818228-4.00001-0

[22] Ren, J., Liu, Y.L., Zhao, X.Y., Cao, J.P. (2020). Methanation of syngas from biomass gasification: An overview. International Journal of Hydrogen Energy, 45(7): 4223-4243. https://doi.org/10.1016/j.ijhydene.2019.12.023

[23] Saradha Devi, G., Vaishnavi, S., Srinath, S., Dutt, B., Rajmohan, K.S. (2020). Energy recovery from biomass using gasification. Current Developments in Biotechnology and Bioengineering, Elsevier, 363-382.

[24] Rasmussen, N.B.K., Aryal, N. (2020). Syngas production using straw pellet gasification in fluidized bed allothermal reactor under different temperature conditions. $\quad$ Fuel, 116706. https://doi.org/10.1016/j.fuel.2019.116706

[25] Singh Siwal, S., Zhang, Q., Sun, C., Thakur, S., Kumar Gupta, V., Kumar Thakur, V. (2020). Energy production from steam gasification processes and parameters that contemplate in biomass gasifier - A review. Bioresource Technology, 297:

122481 . https://doi.org/10.1016/j.biortech.2019.122481

[26] Shahabuddin, M., Alam, M.T., Krishna, B.B., Bhaskar, T., Perkins, G. (2020). A review on the production of renewable aviation fuels from the gasification of biomass and residual wastes. Bioresource Technology, 312: 123596. https://doi.org/10.1016/j.biortech.2020.123596

[27] Díaz González, C.A., Pacheco Sandoval, L. (2020). Sustainability aspects of biomass gasification systems for small power generation. Renewable and Sustainable Energy $\quad$ Reviews, 134 : 110180. https://doi.org/10.1016/j.rser.2020.110180

[28] Hameed, Z., Aslam, M., Khan, Z., Maqsood, K., Atabani, A.E., Ghauri, M., Khurram, M.S., Rehan, M., Nizami, A.S. (2021). Gasification of municipal solid waste blends with biomass for energy production and resources recovery: Current status, hybrid technologies and innovative prospects. Renewable and Sustainable Energy Reviews, 136: 110375 . https://doi.org/10.1016/j.rser.2020.110375

[29] Khiari, B., Jeguirim, M., Limousy, L., Bennici, S. (2019).
Biomass derived chars for energy applications. Renewable and Sustainable Energy Reviews, 108: 253273. https://doi.org/10.1016/j.rser.2019.03.057

[30] Dirgantara, M., Karelius, Ariyanti, M.D., Tamba, S.A.K. (2020). Evaluasi prediksi Higher Heating Value (HHV) biomassa berdasarkan analisis proksimat. Risalah Fisika, 4(1): 1-7. https://doi.org/10.35895/rf.v4i1.166

\section{APPENDIX}

Tables of Combustion Test Results

Table 3. Combustion test result on $0.5 \mathrm{~kg}$ additional fuel

\begin{tabular}{|c|c|c|c|c|c|}
\hline \multirow[b]{2}{*}{ Parameters } & \multirow[b]{2}{*}{ Units } & \multicolumn{4}{|c|}{ Test result } \\
\hline & & $\underset{3}{\operatorname{Min} .}$ & $\underset{6}{\operatorname{Min} .}$ & $\underset{9}{\operatorname{Min} .}$ & $\underset{12}{\operatorname{Min} .}$ \\
\hline $\begin{array}{l}\text { Burning } \\
\text { temperature }\end{array}$ & ${ }^{\circ} \mathrm{C}$ & 44.8 & 63.5 & 74.2 & 74.3 \\
\hline $\begin{array}{c}\text { Water } \\
\text { temperature }\end{array}$ & ${ }^{\circ} \mathrm{C}$ & 43.1 & 67.1 & 67.6 & 66.3 \\
\hline Concentration $\mathrm{CO}$ & Ppm & 14.84 & 12.10 & 12.10 & 11.72 \\
\hline $\begin{array}{c}\text { Concentration } \\
\mathrm{CO}_{2}\end{array}$ & Ppm & 390 & 715 & 665 & 410 \\
\hline
\end{tabular}

Table 4. Combustion test result on $0.3 \mathrm{~kg}$ additional fuel

\begin{tabular}{lcccc}
\hline \multirow{2}{*}{ Parameters } & \multirow{2}{*}{ Units } & \multicolumn{3}{c}{ Test result } \\
& & Min. 3 & Min. 6 & Min. 9 \\
\hline Burning temperature & ${ }^{\circ} \mathrm{C}$ & 72.8 & 65.3 & 72.1 \\
Water temperature & ${ }^{\circ} \mathrm{C}$ & 68.5 & 86.3 & 84.8 \\
Concentration $\mathrm{CO}$ & $\mathrm{Ppm}$ & 13.24 & 12.10 & 11.72 \\
Concentration $\mathrm{CO}_{2}$ & $\mathrm{Ppm}$ & 860 & 390 & 390 \\
\hline
\end{tabular}

Table 5. Combustion test result on $0.2 \mathrm{~kg}$ additional fuel

\begin{tabular}{lccc}
\hline \multirow{2}{*}{ Parameter } & \multirow{2}{*}{ Units } & \multicolumn{2}{c}{ Test result } \\
& & Min. 3 & Min. 6 \\
\hline Burning temperature & ${ }^{\circ} \mathrm{C}$ & 64.6 & 67.7 \\
Water temperature & ${ }^{\circ} \mathrm{C}$ & 87.9 & 84.8 \\
Concentration $\mathrm{CO}$ & $\mathrm{Ppm}$ & 12.47 & 14.04 \\
Concentration $\mathrm{CO}_{2}$ & $\mathrm{Ppm}$ & 605 & 400 \\
\hline
\end{tabular}

